\title{
MITOGENIC EFFECT OF BESTATIN ON LYMPHOCYTES
}

\author{
Masaaki Ishizuka, Junichi Sato, Yuko Sugiyama, Tomio Takeuchi \\ and HAMAO UMEZAWA \\ Institute of Microbial Chemistry \\ 14-23 Kamiosaki 3-Chome, Shinagawa-ku, Tokyo 141, Japan
}

(Received for publication March 10, 1980)

\begin{abstract}
The incorporation of ${ }^{3} \mathrm{H}$-thymidine into the acid insoluble fraction of spleen cells was increased by intraperitoneal injection of $10 \mu \mathrm{g}$ bestatin/mouse. Bestatin $(0.01,0.1,1.0 \mu \mathrm{g} / \mathrm{ml})$ which was added to mouse spleen cell culture increased ${ }^{3} \mathrm{H}$-thymidine incorporation into lymphocytes, but $10 \mu \mathrm{g} / \mathrm{ml}$ did not. This mitogenic action of bestatin was not observed when adherent cells were removed or $\mathrm{T}$ cells were destroyed, suggesting that bestatin causes the proliferate $T$ cells probably through the activation of macrophages. Bestatin given to mice did not modulate mitogenicity of lectins. Bestatin treatment of human peripheral buffy coat cells increased ${ }^{3} \mathrm{H}$-thymidine incorporation into lymphocytes. The addition of bestatin at a high concentration such as $100 \mu \mathrm{g} / \mathrm{ml}$ to mouse spleen cell cultures exhibited a high mitogenic effect on B cells in preference to $\mathrm{T}$ cells but this effect was not seen with bestatin at $50 \mu \mathrm{g} / \mathrm{ml}$. In this case, the mitogenicity of Con A or LPS was expanded and antibody formation to SRBC in spleen cell cultures were also stimulated.
\end{abstract}

As reported in previous papers, bestatin ${ }^{1)}$ produced by streptomyces inhibits aminopeptidases which are membrane-associated enzymes ${ }^{2)}$, binds to cells and enhances immune responses ${ }^{4,5)}$. Bestatin 0.1, 1,10 or $100 \mu \mathrm{g} /$ mouse enhanced delayed-type hypersensitivity to sheep red blood cells but $1,000 \mu \mathrm{g} /$ mouse did not have this effect ${ }^{4,5)}$. As reported in the preceding paper ${ }^{8)}$, bestatin restored delayedtype hypersensitivity reduced by intravenous injection of cyclophosphamide or by intraperitoneal inoculation of EHRLICH carcinoma cells and low doses, 1, 10 or $100 \mu \mathrm{g} /$ mouse, suppressed the growth of slowly growing subcutaneous tumors of GARDNER lymphosarcoma and IMC carcinoma.

In this report, we will report the mitogenic effect of bestatin.

\section{Materials and Methods}

Mice

Specific pathogen-free $\mathrm{CDF}_{1}$ mice $($ Balb/c $\times \mathrm{DBA} / 2$, female, $8 \sim 12$ weeks old) were obtained from Institute of Medical Science, University of Tokyo and were used throughout the experiments unless otherwise noticed.

\section{Bestatin}

Bestatin (Lot 751158TS, NK421, Lot 2) was dissolved in distilled water at $4 \mathrm{mg}$ or $1 \mathrm{mg} / \mathrm{ml}$ for animal experiments or in RPMI 1640 (Nissui Seiyaku Co., Ltd. Tokyo) at $200 \mu \mathrm{g} / \mathrm{ml}$ for cell culture experiments. These solutions were diluted to appropriate concentration with distilled water or RPMI 1640 medium. Bestatin in $0.25 \mathrm{ml}$ was given to each mouse. Bestatin in $0.05 \mathrm{ml}$ was added to spleen cell culture.

\section{Mitogens}

Concanavalin A (Con A, Pharmacia Fine Chemicals AB. Uppsala, Sweden) and phytohaemagglutinin P (PHA-P, Difco Laboratories, Detroit, Mich.) were employed as T cell mitogens and Pokeweed mitogen (PWM, Grand Island Biological Co., N.Y.) and lipopolysaccharide (LPS, Escherichia coli 0111, Difco Laboratories, Detroit, Mich.) as B cell mitogens. 
Mitogenic Action of Bestatin in vivo

Bestatin in $0.25 \mathrm{ml}, 0.1,1,10,100$, or $1,000 \mu \mathrm{g} /$ mouse, was given to mice intraperitoneally, 18 hours thereafter, spleen was taken from each mouse and teased to obtain spleen cells. Spleen cells were suspended in serum-free RPMI 1640 and washed once by $800 \times g$ centrifugation, and suspended in RPMI 1640 supplemented with $5 \%$ heat-inactivated fetal calf serum (FCS, Lot 90380, Microbiological Associates, Bethesda, Md., or Lot 527A Colorado Serum Co. Col.) at $1.5 \times 10^{8} \mathrm{cells} / \mathrm{ml}$. Three $\mathrm{ml}$ of spleen cell suspension was placed in each glass tube $(11 \times 100 \mathrm{~mm})$ with a Morton cap and was incubated at $37^{\circ} \mathrm{C}$ for 3 days in a fully humidified atmosphere of $5 \% \mathrm{CO}_{2}$ and air. Eighteen hours before assay, to each tube was added $1 \mu \mathrm{Ci} /$ tube of ${ }^{3} \mathrm{H}$-thymidine $\left({ }^{3} \mathrm{H}\right.$-TdR, $6{ }^{3} \mathrm{H}$-Thymidine NET-355, New England Nuclear, Boston, Mass.). Thereafter (18 hours after the addition), the incorporation of ${ }^{3} \mathrm{H}-\mathrm{TdR}$ into DNA of cultured cells was determined. Cells from each tube were washed with $5 \mathrm{ml}$ of a cold saline thoroughly and suspended in $0.1 \mathrm{ml}$ of saline. The cell suspension was collected with a pipetman (Gilson France S. A., Villier-le-Bel, France) and was distributed on a glass filter (Whatman, 3MM. Whatman Inc., Clifton, N. J.). The filters were soaked in $5 \%$ trichloroacetic acid for 60 minutes, twice and were dried. The amount of ${ }^{3} \mathrm{H}-\mathrm{TdR}$ incorporated into acid insoluble fraction was determined by liquid scintillation spectrometry and expressed as total count per minute (cpm) per tube.

Mitogenic Effect of Bestatin on Murine Lymphocytes in vitro

Spleen cells prepared from normal mice were suspended in RPMI 1640 medium supplemented with $20 \%$ heat-inactivated FCS at $15 \times 10^{8}$ cells $/ \mathrm{ml}$. This medium was used for cell culture throughout the experiments otherwise stated. Three $\mathrm{ml}$ aliquots of this cell suspension were distributed into Petri dish (Falcon 3002, Div. Becton, Dickinson, and Co. Oxnard, Calif.) and bestatin in $0.15 \mathrm{ml}$ RPMI 1640 was added. They were cultured in a fully humidified atmosphere of $5 \% \mathrm{CO}_{2}$ and air at $37^{\circ} \mathrm{C}$ for 18 hours on a rocking platform $(6 \sim 8$ cycle/min, Bellco Glass Inc., Vineland, N. J.).

Thereafter, non-adherent cells in each culture were collected by centrifugation, and resuspended in $4 \mathrm{ml}$ of medium. The four $\mathrm{ml}$ aliquots were placed on $3 \mathrm{ml}$ of Ficoll-Paque (Pharmacia Fine Chemicals $\mathrm{AB}$, Uppsala, Sweden) and centrifuged at $400 \times g$ for 40 minutes at $20^{\circ} \mathrm{C}$. After centrifugation, lymphocytes layer was collected and washed with serum-free RPMI 1640 three times. Lymphocytes were suspended in the medium at $1.5 \times 10^{8}$ cells $/ \mathrm{ml}$, and $3 \mathrm{ml}$ in a glass tube or $0.2 \mathrm{ml}$ in a well of micro test plate (Falcon 3042) were incubated at $37^{\circ} \mathrm{C}$ for 3 days in a fully humidified atmosphere of $5 \% \mathrm{CO}_{2}$ and air. Triplicate cultures were performed for each condition. Eighteen hours before assay, ${ }^{3} \mathrm{H}-\mathrm{TdR}$ $1 \mu \mathrm{Ci} /$ tube or $0.1 \mu \mathrm{Ci} /$ well was added to each culture and the incorporation of ${ }^{3} \mathrm{H}-\mathrm{TdR}$ into cells was determined. The procedure to measure ${ }^{3} \mathrm{H}-\mathrm{TdR}$ into cells placed in a glass tube was described above. The incorporation of ${ }^{3} \mathrm{H}-\mathrm{TdR}$ into cultures in a microplate was measured by using a cell harvester (Labo Mash, Labo Science Co., Ltd., Tokyo). The amount of ${ }^{3} \mathrm{H}-\mathrm{TdR}$ into cells was determined by a liquid scintillation spectrometry. In the case spleen cells were divided into two populations, T cell-depleted cell population and macrophage-depleted cell population. T cell-depleted cell population was prepared as follows: spleen cells were incubated with $0.2 \mathrm{ml}$ of anti-Thy 1,2 serum (Searle Diagnostic. High Wycombe, England) in $10.8 \mathrm{ml}$ of serum-free RPMI 1640 at $5 \times 10^{7}$ cells $/ \mathrm{ml}$ at $37^{\circ} \mathrm{C}$ for 60 minutes washed twice with serum-free medium and resuspended in $10.8 \mathrm{ml}$ of serum-free medium containing $1 \mathrm{ml}$ of mouse red cell-absorbed complement; one hour thereafter, cells were washed thoroughly and were adjusted to $1.5 \times 10^{6}$ cells $/ \mathrm{ml}$; each culture in a glass tube was contained $3 \mathrm{ml}$ of cell suspension and incubated for 3 days; triplicate cultures were performed; the determination of ${ }^{3} \mathrm{H}$-TdR incorporation was described already.

In a group of experiments, the bestatin-treated spleen cells were treated with anti-Thy 1, 2 serum before sedimentation by Ficoll-Paque. The procedure was the same as described above.

Macrophage-depleted cell population was prepared by methods reported by MosieR ${ }^{7)}$ or IsHIzUKA et al. ${ }^{8)}$.

The mitogenic action of bestatin at a high concentration on spleen cell culture was tested. Spleen cells were suspended in RPMI 1640 supplemented with $10 \% \mathrm{FCS}$ at $1.5 \times 10^{6} \mathrm{cells} / \mathrm{ml}$ and bestatin dissolved in $0.05 \mathrm{ml}$ was added. In some groups, Con A or LPS was added at $0.5 \mu \mathrm{g} / \mathrm{ml}$. Triplicate cultures were performed in $0.2 \mathrm{ml}$ in sterile Micro test II plates (Falcon 3042). Plates were incubated for 
3 days at $37^{\circ} \mathrm{C}$ in a humidified atmosphere of $5 \%$ $\mathrm{CO}_{2}$ and air. The incorporation of ${ }^{3} \mathrm{H}-\mathrm{TdR}$ was determined as described above.

\section{Antibody Formation in vitro}

Antibody formation to SRBC in dissociated spleen cell culture was tested by the method described by Mishell and DutTon ${ }^{9)}$ and Click et al. ${ }^{10)}$.

Mitogenicity of Bestatin on Human Peripheral Blood Lymphocytes in vitro

Human buffy coat cells, which included lymphocytes and monocytes were obtained from 20 $\mathrm{ml}$ of fresh venous blood in heparin by gravity sedimentation and were suspended in RPMI 1640 supplemented with $20 \% \mathrm{FCS}$ at concentration of $4 \times 10^{6}$ cells $/ \mathrm{ml}$. Three $\mathrm{ml}$ aliquots were placed in a Petri dish (Falcon 3002) and added $0.2 \mu \mathrm{g} /$ $\mathrm{ml}$ of bestatin in $0.05 \mathrm{ml}$. Buffy coat cells with bestatin were incubated at $37^{\circ} \mathrm{C}$ for 18 hours in a fully humidified atmosphere of $5 \% \mathrm{CO}_{2}$ and air on a rocking platform. Then, cells were washed and lymphocytes were collected by FicollPaque sedimentation. The following procedures were described as above (Fig. 1).

\section{Results}

Mitogenicity of Bestatin in Mice

As shown in Fig. 2, when spleen cells were taken from mice 18 hours after intraperitoneal injection of mice and ${ }^{3} \mathrm{H}$-TdR incorporation into DNA was examined. Bestatin $10 \mu \mathrm{g} /$ mouse or more increased the incorporation of ${ }^{3} \mathrm{H}-\mathrm{TdR}$.

Fig. 2. The incorporation rate of ${ }^{3} \mathrm{H}-\mathrm{TdR}$ into DNA of spleen cells of mice given bestatin 24 hours before culture.

The standard deviation did not exceed $8 \%$

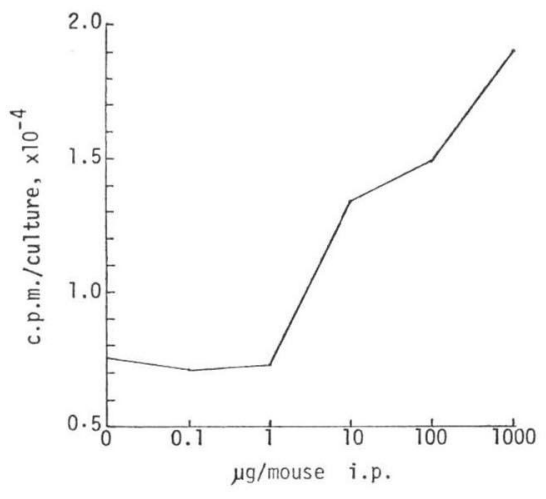

Fig. 1. Procedure for determination of mitogenicity of bestatin in low concentrations in vitro.

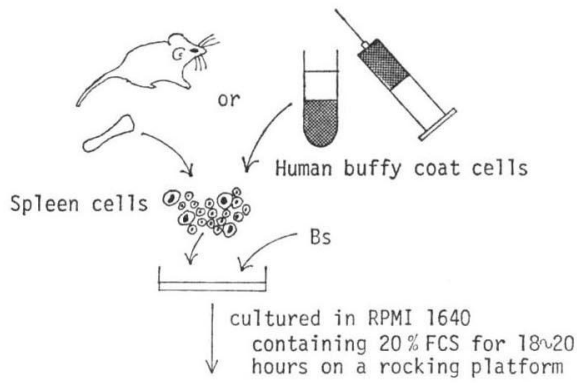

collected non-adherent cells

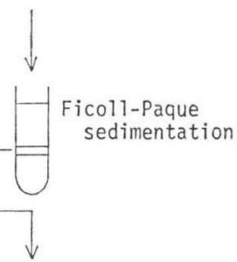

Collected a viable Tymphocytes
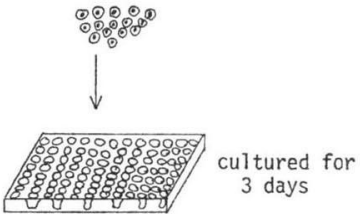

$$
\begin{aligned}
& \downarrow \quad \text { added }{ }^{3} \mathrm{H}-\mathrm{TdR} \\
& \text { (pulse for } 18 \text { hours) } \\
& \text { Determination of }{ }^{3} \mathrm{H} \text {-TdR incorporation } \\
& \text { into cultured 7ymphocytes }
\end{aligned}
$$

Table 1. Incorporation of ${ }^{3} \mathrm{H}-\mathrm{TdR}$ into spleen cells

\begin{tabular}{|c|c|c|c|}
\hline \multirow[t]{2}{*}{ Treatment of mice } & \multicolumn{3}{|c|}{$\begin{array}{l}\text { Mitogens added to the } \\
\text { culture } \\
\text { c.p.m./culture }\end{array}$} \\
\hline & none & $\begin{array}{c}\text { PHA } \\
(0.3 \%)\end{array}$ & $\begin{array}{l}\text { PWM } \\
(3.0 \%)\end{array}$ \\
\hline None & 7,575 & 20,335 & 33,948 \\
\hline Bestatin $1,000 \mu \mathrm{g}$ & 19,015 & 24,822 & 42,533 \\
\hline $100 \mu \mathrm{g}$ & 14,794 & 20,321 & 32,889 \\
\hline $10 \mu \mathrm{g}$ & 13,415 & 22,796 & 33,748 \\
\hline $1 \mu \mathrm{g}$ & 7,279 & 18,713 & 29,575 \\
\hline
\end{tabular}
taken from mice treated with bestatin in the presence and absence of mitogens.

Bestatin was given to mice and 24 hours thereafter, spleen cells were collected and $3 \mathrm{ml}$ aliquots $\left(4.5 \times 10^{6}\right.$ cells $)$ were cultured with or without mitogens in a glass tube for 3 days in $5 \% \mathrm{CO}_{2}$ and air. ${ }^{3} \mathrm{H}-\mathrm{TdR}(1 \mu \mathrm{Ci} /$ culture) was added 18 hours before the harvest of cultured cells. Triplicate cultures were performed in each group. The standard deviation did not exceed $5 \%$. 
The rate of incorporation increased parallel to the increase of bestatin dose up to $1 \mathrm{mg} / \mathrm{mouse}$. At this dose the incorporation reached the plateau. This effect of bestatin increasing ${ }^{3} \mathrm{H}-\mathrm{TdR}$ incorporation can reflect its mitogenic effect on lymphocytes.

To determine whether bestatin augmented the mitogenic effect of mitogens on splenic lymphocytes, spleen cells taken from mice to which bestatin $10 \mu \mathrm{g}$ or $1 \mathrm{mg}$ was given were cultured with PHA or with PWM and the incorporation rate of ${ }^{3} \mathrm{H}-\mathrm{TdR}$ into DNA of cells was measured. As shown in Table 1, the effect of mitogens on spleen cells taken from mice to which $1 \mathrm{mg}$ of bestatin had been given was slightly enhanced. Bestatin $10 \mu \mathrm{g}$ or $100 \mu \mathrm{g} /$ mouse did not show any effect on mitogen-stimulated blastogenesis.

\section{Mitogenic Effect of Bestatin on Murine Splenic}

\section{Lymphocytes In Vitro}

The mitogenic effect of bestatin at concentrations lower than $10 \mu \mathrm{g} / \mathrm{ml}$ in vitro was examined. Spleen cells which contained whole cell populations were treated with bestatin for 18 hours. After bestatin treatment, non-adherent cells were collected and washed thoroughly out to remove bestatin completely. The non-adherent cells thus obtained were sedimented in Ficoll-Paque and lymphocytes were collected. The lymphocytes thus obtained were cultured for 3 days and the incorporation of ${ }^{3} \mathrm{H}-$ TdR into cells were determined. As shown in Table 2, treatment with bestatin in lower doses enhanced incorporation of ${ }^{3} \mathrm{H}-\mathrm{TdR}$ into splenic lymphocytes by $50 \%$ to $100 \%$, although with a high dose, $10 \mu \mathrm{g} /$

Table 2. Incorporation of ${ }^{3} \mathrm{H}$-TdR into lymphocytes separated from spleen cells pretreated with bestatin in vitro.

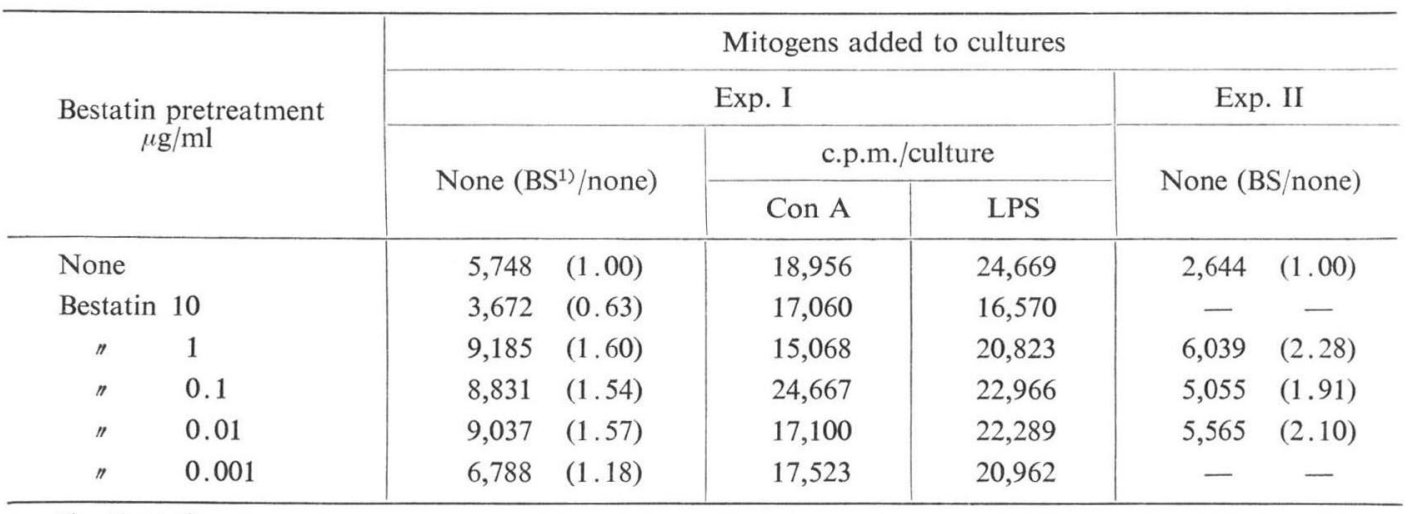

1) Bestatin

The standard deviation did not exceed $8 \%$.

Table 3. Influence of fetal calf serum (FCS) on mitogenic action of bestatin (BS) to splenic lymphocytes in vitro.

\begin{tabular}{l|c|c|c|c|c}
\hline \multicolumn{2}{c}{ Pretreatment with } & \multicolumn{4}{|c}{ Lymphocytes cultures } \\
\cline { 3 - 6 } \multicolumn{2}{c}{ BS } & \multirow{2}{*}{ FCS } & \multicolumn{2}{|c}{ without FCS } & \multicolumn{2}{c}{ with FCS } \\
\cline { 3 - 6 } & & c.p.m./culture & BS/none & c.p.m./culture & BS/none \\
\hline None & none & 154 & 1.00 & 1,722 & 1.00 \\
Bestatin & none & 338 & 2.19 & 2,251 & 1.30 \\
None & FCS & 334 & 1.00 & 4,385 & 1.00 \\
Bestatin & FCS & 764 & 2.28 & 9,737 & 2.22 \\
\hline
\end{tabular}

Spleen cells or lymphocytes were cultured with or without $20 \%$ FCS. Bestatin was added to spleen cell cultures at $1 \mu \mathrm{g} / \mathrm{ml}$. The standard deviation did not exceed $8 \%$. 
Table 4. Correlation between cell cluster formation and incorporation of ${ }^{3} \mathrm{H}-\mathrm{TdR}$ in lymphocyte cultures treated with or without bestatin.

\begin{tabular}{l|c|c|c|c}
\hline \multirow{2}{*}{ Bestatin pretreatment } & \multicolumn{3}{|c}{ Lymphocyte cultures } \\
\cline { 2 - 5 } & No. of cluster/culture & BS $^{1 /} /$ none & c.p.m./culture & BS/none \\
\hline None & $112.3 \pm 12.6$ & 1.00 & $5,964 \pm 257$ & 1.00 \\
Bestatin, $0.01 \mu \mathrm{g} / \mathrm{ml}$ & $210.0 \pm 5.1$ & 1.87 & $13,270 \pm 433$ & 2.22 \\
\hline
\end{tabular}

1) Bestatin

Clusters were enumerated by microscopy $(\times 200) 3$ days after the start of the lymphocyte culture.

Table 5. Incorporation of ${ }^{3} \mathrm{H}-\mathrm{TdR}$ to lymphocytes separated from whole spleen cells, T-depleted cells, and macrophage-depleted cells treated with bestatin.

\begin{tabular}{|c|c|c|c|}
\hline \multirow{2}{*}{$\begin{array}{l}\text { Treatment of } \\
\text { spleen cells }\end{array}$} & \multirow{2}{*}{$\begin{array}{l}\text { Bestatin } \\
\text { treatment }\end{array}$} & \multicolumn{2}{|c|}{$\begin{array}{l}\text { Lymphocyte } \\
\text { cultures }\end{array}$} \\
\hline & & $\begin{array}{l}\text { c.p.m./ } \\
\text { culture }^{1)}\end{array}$ & BS/none \\
\hline \multirow[t]{2}{*}{ None } & None & 17,979 & 1.54 \\
\hline & $\mathrm{BS}^{2)}$ & 27,620 & \\
\hline \multirow[t]{2}{*}{ T Cell-depletion } & None & 19,457 & 0.93 \\
\hline & BS & 18,122 & \\
\hline \multirow[t]{2}{*}{ Macrophage-depletion } & None & 15,208 & 0.99 \\
\hline & BS & 15,136 & \\
\hline
\end{tabular}

1) mean c.p.m. of triplicate cultures. The standard deviation did not exceed $5 \%$.

2) Bestatin, $1 \mu \mathrm{g} / 15 \times 10^{6} \mathrm{cells} / \mathrm{ml}$
Table 6. Elimination of bestatin (BS) mitogenic action to lymphocytes by treatment with anti-Thy 1,2 serum and complement.

\begin{tabular}{l|c|c|c}
\hline \multirow{2}{*}{$\begin{array}{c}\text { T Cell-depletion } \\
\text { after bestatin } \\
\text { treatment }\end{array}$} & \multicolumn{3}{|c}{$\begin{array}{c}\text { Treatment of whole spleen } \\
\text { cell cultures } \\
\text { c.p.m./culture }\end{array}$} \\
\cline { 2 - 4 } & $\begin{array}{c}\text { without } \\
\text { BS (a) }\end{array}$ & $\begin{array}{c}\text { with } \\
\text { BS (b) }\end{array}$ & b/a \\
\hline None & 15,132 & 29,370 & 1.94 \\
T Cell-depleted & 14,715 & 12,534 & 0.85 \\
\hline
\end{tabular}

Spleen cells were treated with $1 \mu \mathrm{g} / \mathrm{ml}$ of bestatin for 18 hours and were treated with anti-Thy 1,2 serum and complement, then, the cells were sedimented in Ficoll-Paque. Lymphocytes were collected and cultured. The standard deviation did not exceed $5 \%$.

$\mathrm{ml}$, the effect was not observed. Mitogenicity of Con A or LPS on lymphocytes was not stimulated by the pretreatment with bestatin.

To determine whether FCS in medium influences the effect of bestatin, spleen cells were cultured with bestatin in medium with or without FCS and after sedimentation, lymphocytes from each culture were cultured in medium with or without FCS. As shown in Table 3, in all cases bestatin pretreatment stimulated the incorporation of ${ }^{3} \mathrm{H}-\mathrm{TdR}$. FCS addition to the medium, especially the addition to the lymphocyte culture increased ${ }^{3} \mathrm{H}-\mathrm{TdR}$ incorporation.

The mitogenicity of bestatin on lymphocytes were accompanied with the formation of cell cluster in cultures. The cell clusters were consisted of a mass of cells, more than 100 cells, and were broken easily to single cells by dispersion using a pasteur pipette. Although clusters were also observed in lymphocyte cultures prepared from non-treated spleen cells, the number of clusters was significantly smaller than that of bestatin-treated group. The number of clusters in cultures was counted by a microscope at $\times 200$. As shown in Table 4, bestatin pretreatment of spleen cells increased the cell clusters in lymphocyte cultures and this increase was in a good agreement with the incorporation of ${ }^{3} \mathrm{H}-\mathrm{TdR}$ into lymphocytes.

In order to determine which lymphocytes in spleen cells are activated by pretreatment with bestatin to increase incorporation of ${ }^{3} \mathrm{H}-\mathrm{TdR}$, spleen cells taken from non-treated normal mice were divided into three cell populations: non-treated whole spleen cell population, T-depleted spleen cell population (Spleen cells were treated with anti-Thy 1, 2 serum and complement) and macrophage-depleted spleen cells (Adherent cells were removed). Thereafter, each cell population of these divided cells was cultured 
in RPMI 1640 containing $20 \% \mathrm{FCS}$ and $1.0 \mu \mathrm{g}$ of bestatin on a rocking platform for 18 hours at $37^{\circ} \mathrm{C}$ in an atmosphere of $5 \% \mathrm{CO}_{2}$ and air. After 18 hours bestatin treatment, non-adherent cells were sedimented in Ficoll-Paque to remove dead non-adherent granulocytes. Thereafter, lymphocytes in each group were washed thoroughly, cultured for 3 days and the incorporation of ${ }^{3} \mathrm{H}-\mathrm{TdR}$ into each culture was determined.

As shown in Table 5, lymphocytes separated from whole spleen cell culture treated with bestatin, resulted in increased incorporation of ${ }^{3} \mathrm{H}-\mathrm{TdR}$ into lymphocytes by about $50 \%$. On the contrary, bestatin treatment of T-depleted or macrophage-depleted spleen cell population did not increase the incorporation of ${ }^{3} \mathrm{H}-\mathrm{TdR}$. These results indicate that macrophages are required for the mitogenic action of bestatin to $\mathrm{T}$ cells.

In order to determine whether bestatin treatment causes the proliferation of $\mathrm{T}$ cells, whole spleen cells were cultured with bestatin for 18 hours and bestatin-stimulated lymphocytes were collected. Thereafter, this lymphocyte population was treated with anti-Thy 1,2 serum and complement. After Ficoll-Paque sedimentation, lymphocytes were collected and cultured for 3 days and the incorporation of ${ }^{3} \mathrm{H}-\mathrm{TdR}$ into lymphocytes was measured. As shown in Table 6, the incorporation into lymphocytes from bestatin-treated spleen cells was increased about 2 times, but by treating with anti-Thy 1, 2 serum and complement, this increase was eliminated. These results suggest that bestatin causes the proliferation of $\mathrm{T}$ cells probably through the activation of macrophages.

\section{Mitogenicity of Bestatin on Human Peripheral \\ Blood Lymphocytes In Vitro}

Human buffy coat cells containing lymphocytes and monocytes were prepared from each $20 \mathrm{ml}$ of venous blood of two normal healthy donors and cultured bestatin with $0.2 \mu \mathrm{g} / \mathrm{ml}$. Eighteen hours thereafter, lymphocytes were collected and cultured for 3 days. As shown in Table 7, bestatin exhibited its mitogenic action on human peripheral lymphocytes. In two cases shown in Table 7 , bestatin treatment of buffy coat cells caused to increase the incorporation of ${ }^{3} \mathrm{H}$ TdR into lymphocytes about 2 or 3 times.

Table 7. ${ }^{3} \mathrm{H}-\mathrm{TdR}$ incorporation to human lymphocytes separated from buffy coat cells treated with bestatin.

\begin{tabular}{c|l|r|r}
\hline \multirow{2}{*}{$\begin{array}{c}\text { Buffy coat cells } \\
\text { from }\end{array}$} & $\begin{array}{c}\text { Bestatin } \\
\text { treatment }\end{array}$ & \multicolumn{2}{|c}{ Lymphocytes culture } \\
\cline { 3 - 4 } & $\begin{array}{c}\text { c.p.m/ } \\
\text { culture }\end{array}$ & $\begin{array}{c}\text { Bestatin/ } \\
\text { none }\end{array}$ \\
\hline \multirow{2}{*}{ H. I. } & None & 2,060 & 1.00 \\
& Bestatin & 4,802 & 2.33 \\
T. S. & None & 990 & 1.00 \\
& Bestatin & 2,905 & 2.93 \\
\hline
\end{tabular}

The standard deviation did not exceed $5 \%$.

Mitogenicity of Bestatin Added to Spleen Cell Cultures and its Effect on Antibody Formation In Vitro

The effect of addition of high concentrations of bestatin to mouse spleen cell cultures was examined. Spleen cell cultures were added bestatin at $0.01,0.1,100 \mu \mathrm{g} / \mathrm{ml}$ and cultured for 3 days at $37^{\circ} \mathrm{C}$ in $5 \%$ $\mathrm{CO}_{2}$ and air. The effect was examined by measuring the incorporation of ${ }^{3} \mathrm{H}-\mathrm{TdR}$ into cells. As shown in Table 8, the incorporation of ${ }^{3} \mathrm{H}-\mathrm{TdR}$ into spleen cells was increased only in the case of addition of bestatin $100 \mu \mathrm{g} / \mathrm{ml}$ and compared with the control, the incorporation was increased by about 5 times. The addition of $100 \mu \mathrm{g} / \mathrm{ml}$ was also stimulated mitogenic action of Con A and LPS on spleen cells. Bestatin and each mitogen were added to spleen cell cultures simultaneously. Bestatin less than $50 \mu \mathrm{g} / \mathrm{ml}$ showed no effect.

To determine which cell population in spleen is stimulated by addition of bestatin $100 \mu \mathrm{g} / \mathrm{ml}$, 
spleen cells were divided into three cell populations: whole spleen cells, macrophage-depleted and T celldepleted spleen cells. These cell populations were cultured with bestatin $100 \mu \mathrm{g} / \mathrm{ml}$ for 3 days. The incorporation of ${ }^{3} \mathrm{H}-\mathrm{TdR}$ was determined and stimulatory effect of bestatin was estimated by mitogenic index in each cell population. As shown in Table 9, addition of each bestatin dose, Con A or LPS alone increased the incorporation of ${ }^{3} \mathrm{H}-\mathrm{TdR}$ into whole spleen cells. The addition of bestatin stimulated the incorporation 2.6 times. Bestatin at $100 \mu \mathrm{g} / \mathrm{ml}$ also increased the incorporation of ${ }^{3} \mathrm{H}$-TdR into T celldepleted spleen cells as well as non-treated whole spleen cells. Bestatin of macrophage-depleted spleen cells was observed with a reduction of about $50 \%$. These results indicate that the high concentration of bestatin stimulates B cells, partly through activation of macrophages. The effect of Con A or LPS on macrophage-depleted spleen cells was reduced in both cases, particularly the mitogenic index of Con A or LPS was reduced by $86 \%$ or $63 \%$ compared with non-treated spleen cells. On T cell-depleted spleen cells, the mitogenic index of Con A was reduced markedly and the effect of LPS was affected slightly.

In combination with bestatin, although bestatin stimulated the mitogenic index of Con A on spleen cells by $40 \%$, that of LPS was stimulated by more than $100 \%$. The stimulatory effect on LPS was observed in parallel with the mitogenic index of bestatin alone, and on macrophage- or T cell-depleted spleen cells, the addition of bestatin also stimulated the mitogenicity of Con A or LPS in parallel with the index of bestatin alone. Results indicate that in combination with Con A and LPS, bestatin can enhance the mitogenicity of Con A and LPS.

These results suggest that the addition of bestatin at $100 \mu \mathrm{g} / \mathrm{ml}$ to spleen cells stimulate B cell and

Table 8. The mitogenic action of bestatin (BS) added to spleen cell cultures

\begin{tabular}{c|c|c|c|c|c|c}
\hline \multirow{2}{*}{ Bestatin $\mu \mathrm{g} / \mathrm{ml}$} & \multicolumn{3}{|c}{ Addition to spleen cell cultures } \\
\cline { 2 - 7 } & \multicolumn{2}{|c|}{ none } & \multicolumn{2}{c}{ Con A } & \multicolumn{2}{c}{ LPS } \\
\cline { 2 - 7 } & c.p.m./culture & BS/none & c.p.m./culture & BS/none & c.p.m./culture & BS/none \\
\hline 100 & 3,678 & 4.99 & 26,631 & 1.55 & 12,844 & 2.92 \\
1 & 699 & 0.95 & 18,843 & 1.09 & 4,304 & 0.98 \\
0.01 & 777 & 1.05 & 15,842 & 0.92 & 4,321 & 0.98 \\
0 & 737 & 1.00 & 17,232 & 1.00 & 4,388 & 1.00 \\
\hline
\end{tabular}

Spleen cells $\left(1.5 \times 10^{6}\right.$ cells $\left./ \mathrm{ml}\right)$ were cultured with or without bestatin and $0.5 \mu \mathrm{g} / \mathrm{ml}$ of Con A or LPS for 3 days. The cultures were performed in triplicate and the standard deviation did not exceed $5 \%$.

Table 9. Mitogenic activity of bestatin added to macrophage- and $\mathrm{T}$ cell-depleted spleen cell cultures

\begin{tabular}{l|c|c|c|c|c|c}
\hline \multirow{2}{*}{$\begin{array}{c}\text { Addition to } \\
\text { cultures }\end{array}$} & \multicolumn{5}{|c}{ Mitogenic index ${ }^{1)}$ of spleen cells } \\
\cline { 2 - 7 } & \multicolumn{2}{|c|}{ Non-treated } & Macrophage-depleted & \multicolumn{2}{c}{ T Cell-depleted } \\
\cline { 2 - 7 } & None & Bestatin & None & Bestatin & None & Bestatin \\
\hline None & $1.0^{\mathrm{a})}$ & 2.6 & $1.0^{\mathrm{b})}$ & 1.5 & $1.0^{\mathrm{c})}$ & 2.1 \\
Con A & $14.2(1.0)^{2)}$ & $19.9(1.4)$ & $2.3(1.0)$ & $3.6(1.6)$ & $1.8(1.0)$ & $3.9(2.2)$ \\
LPS & $8.7(1.0)$ & $18.5(2.1)$ & $3.2(1.0)$ & $4.5(1.4)$ & $6.1(1.0)$ & $11.6(1.9)$ \\
\hline
\end{tabular}
a) $512 \pm 8.3$ c.p.m./culture
b) $4,739 \pm 112.3$ c.p.m./culture c) $590 \pm 17.5$ c.p.m./culture
1) Mitogenic index (M. I.) c.p.m. of each cell culture added mitogens or/and bestatin c.p.m. of each cell culture alone
2) A parenthesis: Ratio in cultures added mitogens $=\frac{\text { M. I. of each cell culture with bestatin }}{\text { M. I. of each cell culture without bestatin }}$ 
enhance to proliferate $\mathrm{T}$ cells slightly, since the addition could stimulate $\mathrm{T}$ cell-depleted spleen cells in almost parallel index that of non-treated spleen cells, and the stimulation may partly be mediated by macrophages. It is also shown that bestatin can enhance the mitogenicity of $\mathrm{T}$ and $\mathrm{B}$ cell mitogens.

The effect of bestatin on antibody formation was tested in vitro. Spleen cell cultures were added $1 \mu \mathrm{g}$ to $100 \mu \mathrm{g} / \mathrm{ml}$ of bestatin and were cultured with SRBC as antigen for 4 days. The number of antibody-forming cells was enumerat. ed in terms of plaque forming cells. As shown in Fig. 3, antibody-forming cells were increased about 3.4 folds in addition of bestatin $100 \mu \mathrm{g} / \mathrm{ml}$. The stimulatory effect was also observed in parallel with the incorporation rate of ${ }^{3} \mathrm{H}$-TdR into spleen cells.

These effects of bestatin on spleen cell cultures were not observed in the case of its lower concentration than $10 \mu \mathrm{g} / \mathrm{ml}$.
Fig. 3. Correlation between antibody formation and incorporation rate of ${ }^{3} \mathrm{H}-\mathrm{TdR}$ in spleen cell cultures added bestatin.

The standard deviation did not exceed $10 \%$ in No. of PFC and $5 \%$ in c.p.m.

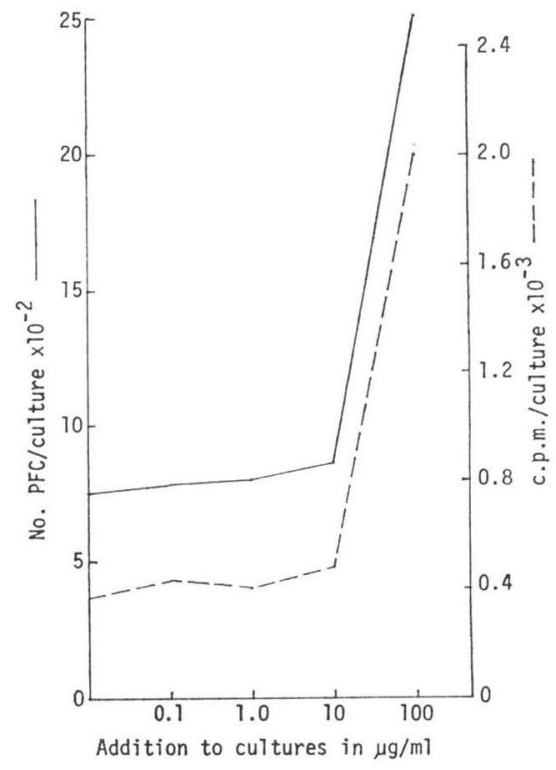

\section{Discussion}

As described in preceding reports ${ }^{4,6)}$, bestatin was effective in augmenting cell-mediated immunity in lower doses and retarded syngeneic solid tumors depending on timing of administration in mice. These effects of bestatin were not observed at higher doses, more than $1 \mathrm{mg} / \mathrm{mouse}$. Therefore, the action of bestatin was studied in low doses or low concentrations, less than $100 \mu \mathrm{g} / \mathrm{mouse}$ or $10 \mu \mathrm{g} / \mathrm{ml}$, on lymphoid cells. The administration of bestatin to mice stimulated the incorporation rate of ${ }^{3} \mathrm{H}-$ $\mathrm{TdR}$ into DNA of spleen cells in doses of more than $10 \mu \mathrm{g} /$ mouse.

It was felt that the effect of bestatin reflects its mitogenic activity on murine lymphocytes and we attempted to determine its effect in spleen cell cultures. The addition of less than $10 \mu \mathrm{g} / \mathrm{ml}$ bestatin to the cell culture system did not show any effects. Therefore, spleen cells which include lymphocytes and macrophage were pretreated with bestatin. After pretreatment, lymphocytes were collected and incorporation rate of ${ }^{3} \mathrm{H}-\mathrm{TdR}$ into lymphocyte was tested. Mitogenicity was observed in lower concentrations, $1 \mu \mathrm{g}$ to $0.01 \mu \mathrm{g} / \mathrm{ml}$. The effect was not observed at concentration of $10 \mu \mathrm{g} / \mathrm{ml}$.

The effect of bestatin was only observed in lymphocytes from bestatin-treated spleen cells which included $\mathrm{T}$ cells and adherent cells but not in lymphocytes from bestatin-treated spleen cells from which $\mathrm{T}$ cells and/or adherent cells were removed. Results shown in Tables 6 and 7 indicate that bestatin activated macrophages and/or $\mathrm{T}$ cells and the activation provides proliferation of $\mathrm{T}$ cells. Hence, we have two possible explanation concerning the mitogenicity of bestatin: (1) Bestatin primarily activates $\mathrm{T}$ cells, which produce lymphokines for activation of macrophages and macrophage activation stimulates $\mathrm{T}$ cell proliferation. (2) Bestatin primarily activates macrophages and macrophage activation provides to stimulate proliferation of $\mathrm{T}$ cells. In both cases, however, bestatin stimulates proliferation of $\mathrm{T}$ cells through activation of macrophages ${ }^{11,12}$.

Recently, MÜLLER et al. ${ }^{13)}$ showed that administration of bestatin provide to increase incorporation of ${ }^{3} \mathrm{H}-\mathrm{TdR}$ only into $\mathrm{T}$ cells but not into B cells. The results in this report confirm this observation. 
As reported previously high concentration, $50 \mu \mathrm{g} / \mathrm{ml}$ of bestatin also stimulates mitogenicity of Con A or PHA-P on small lymphocytes of guinea pig $^{14,15}$. In this case, the lymphocytes might be not included sufficient macrophages to be activated by bestatin. As shown in Table 3, mitogenicity of Con A or LPS was not enhanced on lymphocytes stimulated by low concentration of bestatin. The difference can be explained as a dose-dependent effect of this substance.

The addition of $100 \mu \mathrm{g} / \mathrm{ml}$ of bestatin to cultures exhibited a high mitogenic response on spleen cells. Bestatin also enhanced the mitogenicity of Con A or LPS. The experiment shown in Table 9 indicates that the addition of high concentration of bestatin is mitogenic on B cells for the most part of its effect and on $\mathrm{T}$ cells, partly through activation of macrophages. The high concentration was also effective in enhancing antibody formation against SRBC in vitro. The stimulatory effect on antibody formation was shown to be parallel with the incorporation rate of ${ }^{3} \mathrm{H}-\mathrm{TdR}$. It can be noticed that bestatin did not stimulate the generation of suppressor cells on antibody formation to SRBC in vitro.

Bestatin is mitogenic on splenic lymphocytes, in low concentration, less than $1 \mu \mathrm{g} / \mathrm{ml}$. The mitogenicity on $\mathrm{T}$ cells can be observed by pretreatment of macrophage and $\mathrm{T}$ cells with it and in high concentration, $100 \mu \mathrm{g} / \mathrm{ml}$, the mitogenicity mainly on B cells, can be observed by addition to spleen cell cultures. The mechanisms of mitogenicity of the high and low concentrations remain to be clarified. The mitogenicity in low concentration may reflect action of bestatin in enhancement of DTH or in retardation of tumor growth in animals. Therefore, bestatin enhancing immune responses in animal through activation of macrophages and T cells, but in high dose, bestatin may activate B cells.

\section{Acknowledgements}

This work was partly supported by a Grant-in-Aid for Cancer Research from the Ministry of Education, Science and Culture, Japan and a Contract No. NO1-CM-57009 from the Division of Cancer Treatment, National Cancer Institute, U. S. A.

\section{References}

1) Umezawa, H.; T. Aoyagi, H. Suda, M. Hamada \& T. Takeuchi: Bestatin, an inhibitor of aminopeptidase B produced by actinomycetes. J. Antibiotics 29: $97 \sim 99,1976$

2) Aoyagi, T.; H. Suda, M. Nagai, K. Ogawa, J. Suzuki, T. Takeuchi \& H. Umezawa: Aminopeptidases activities on the surface of mammalian cells. Biochim. Biophys. Acta 452: $131 \sim 143,1976$

3) Aoyagi, T.; M. Ishizuka, T. Takeuchi \& H. Umezawa: Enzyme inhibitors in relation to cancer therapy. Jap. J. Antibiotics 30 (Suppl.): 121 132, 1977

4) Umezawa, H.; M. Ishizuka, T. Aoyagi \& T. Takeuchi: Enhancement of delayed-type hypersensitivity by bestatin, an inhibitor of aminopeptidase. J. Antibiotics 29: 857 859, 1976

5) Umezawa, H.: Recent advances in microbial secondary metabolites: Inhibitors of hydrolytic enzymes. In "Kinins II: Systemic Proteases and Cellular Function", S. FuJI, H. MoriYA \& T. Suzuki, Eds., pp. 319 340, Plenum Publishing Co., 1979

6) Ishizuka, M.; T. Masuda, N. Kanbayashi, S. Fukasawa, T. Takeuchi, T. Aoyagi \& H. Umezawa: Effect of bestatin on mouse immune system and experimental murine tumors. J. Antibiotics 33: 642 652, 1980

7) Mosier, D. E.: A requirement for two cell types for antibody formation in vitro. Science 158: 1573 1575,1967

8) Ishizuka, M.; W. Braun \& T. Matsumoto: Cyclic AMP and immune responses. I. Influence of poly A : U and cAMP on antibody formation in vitro. J. Immunol. 107: 1027 1035, 1971

9) Mishell, R. I. \& R. W. Dutton: Immunization of dissociated spleen cell cultures from normal mice. J. Exp. Med. 126: 423 442, 1967

10) Click, R. E.; L. Benck \& B. J. Alter: Enhancement of antibody synthesis in vitro by mercaptoethanol. Cell. Immunol. 3: 156 160, 1972

11) Greinder, D. K. \& A. S. Rosenthal: The requirement for macrophage-lymphocyte interaction in T lymphocyte proliferation induced by generation of aldehydes on cell membranes. J. Immunol. 115: 932 938, 1975

12) Rosenwasser, L. J. \& A. S. Rosenthal: Adherent cell function in murine T lymphocyte antigen recogni- 
tion. I. A macrophage-dependent T cell proliferation assay in the mouse. J. Immunol. 120: 1991 1995, 1978

13) Müller, W. E. G.; R. K. Zahn, J. Arendes, N. Munsch \& H. UmeZawa : Activation of DNA metabolism in T cells by bestatin. Biochem. Pharmacol. 28: 3131 3137, 1979

14) Saito, M.; T. Aoyagi, H. Umezawa \& Y. Nagai: Bestatin, a new specific inhibitor of aminopeptidases, enhances activation of small lymphocytes by concanavalin A. Biochem. Biophys. Res. Commun. 76: 526 533,1977

15) Saito, M.; K. Takegoshi, T. Aoyagi, H. Umezawa \& Y. Nagai: Stimulatory effect of bestatin, a new specific inhibitor of aminopeptidases, on the blastogenesis of guinea pig lymphocytes. Cell. Immunol. 40: $247 \sim 262,1978$ 